\title{
DETERMINING THE ECOLOGICAL FOOTPRINT OF VEHICLES IN TEHRAN, IRAN
}

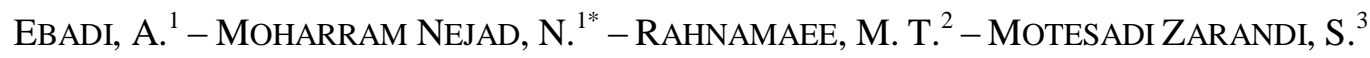 \\ ${ }^{I}$ Department of Environment, Science and Research Branch, Islamic Azad University, Tehran, \\ Iran \\ ${ }^{2}$ Department of Geography, University of Tehran, Tehran, Iran \\ ${ }^{3}$ Department of Health and Environment, Shahid Beheshti University, Tehran, Iran \\ *Corresponding author \\ e-mail: abasebadi20@yahoo.com,moharamnejad@gmail.com
}

(Received $10^{\text {th }}$ Mar 2016; accepted $23^{\text {rd }}$ Apr 2016)

\begin{abstract}
Inefficient transport system in big cities such as Tehran causes major environmental problems like increasing fuel consumption, which results in the loss of large amounts of non-renewable natural resources. Increased fuel consumption in Tehran is mainly due to lack of an integrated and efficient transport system, which is one of the main causes of the decline in the country's environmental resources. The aim of this paper is to estimate the ecological footprint of energy in the transportation system within city of Tehran and also estimate the ecological footprint for each of the vehicles per passenger. Finally, some suggestions for improving the sustainability of the transportation system in Tehran will be made. To achieve this goal, the amount of fuel consumption in the transportation sector within city of Tehran was prepared and, based on the carbon release from any type of fuels, energy footprint in 2012 was estimated. Also, fuel consumption per passenger of vehicles was calculated and the ecological footprint per passenger for any type of vehicles was calculated using the ecological footprint model. The results showed that the ecological footprint of energy in the transportation sector in Tehran was 4,384,777.5 gha in 2012, while the total forest land in city of Tehran was equal to 7670.5 ha. So, this ecological deficit showed an unsustainable transport system in Tehran. The results also demonstrated that the subway system, with $0.002 \mathrm{~m}^{2}$ per passenger, had minimum ecological footprint and private cars with 1.612 $\mathrm{m}^{2}$ per passenger had the highest ecological footprint. This means that each passenger of a private vehicle has footprints equal to 806 times of a subway passenger.
\end{abstract}

Keywords: ecological footprint, transportation, Tehran, energy footprint, fuel consumption

\section{Introduction}

In recent decades, the rapid increase in the human population with increasing humanitarian needs has imposed heavy pressures on the limited resources of the earth. Increasing the human population and, consequently, increasing urbanization and city expansion demand more features and needs than the past. In these conditions, lack of proper planning in the development of the infrastructure of the city puts the sustainability of town and environment at risk. One of the main problems of cities is transportation system and, in city of Tehran, problems resulting from this sector can be clearly noticed (Faryadi and Samadpoor, 2010). Population growth of Tehran increases daily urban trips. Rise of daily trips has environmental consequences such as increasing fuel consumption, loss of national natural resources, and air pollution, reducing quality of urban environment, and ultimately, threatening health and welfare of citizens. Now, due to the effects of transportation and heavy traffic in Tehran, it is essential to comprehensively assess environmental quality and provide suitable transport methods to reduce the harmful effects. For this purpose, the ecological footprint can be used as a 
quantitative and comprehensive method for determining the quality of urban environment. The concept of the ecological footprint, for the first time, was introduced by William Rees and Mathis Wackernagel in 1996 at University of British Columbia, Canada. The ecological footprint reflects the amount of consumption or demand for natural goods and services. Ecological footprint is equivalent to the amount of land or water surface, which provides the consumption needs of the community or absorbs the produced waste by them. In other words, the ecological footprint reflects the effects that societies put on the nature due to their life style (Peters and Schouten, 2010). Innovation of ecological footprint method is that, unlike traditional methods, environmental impact assessment is not entirely qualitative and, in this method, there is a factual basis for decision-making, which makes the amount of consumption to the "earth" (Sarayiand Zarei, 2009). Therefore, in the ecological footprint method, evaluation and comparison of the consumption amount of environmental resources have been used in cities and urban neighborhoods (Samadpoor and Faryadi, 2008).

\section{Review of Literature}

In recent years, ecological footprint has been used as a tool for assessing the urban and environmental resources, in different countries. Including, Philip Woods in 2004, calculated amount of ecological footprint for the north shores of Sydney (Woods, 2005).

Mark Anielski and Jeffrey Wilson in 2005 calculated ecological footprint of Canada and its various cities including Vancouver, Calgary, Edmonton and other cities and then compared with the ecological footprint of other countries. (Wilson and Anielski, 2005).

Footprint of transportation in the United States of America, Considering all kinds of vehicles ranging from private cars and trucks, motorcycles and buses, rail and air transport and passenger boats, and regarding this point that how much $\mathrm{CO} 2$ is released to atmosphere for consuming per $\mathrm{KWH}$ of each fuel, was estimated at 1.94 global hectares (McIntyre et al., 2007).

In Great Britain in 2003, with regard to the water, air and rail transport , metro, buses, cars, motorbikes and scooters, and regarding infrastructures, ecological footprint of transportation of 0.67 Global hectares was calculated (Barret and Simmons, 2003).

Footprint of transportation in the city of Adelaide in Australia with regard to the use of private vehicles like cars and trucks, motorcycles, buses, rail and air transport and passenger boats was calculated as 0.66 Global hectares per capita (Agrawal et al., 2006).

In the city of Kermanshah in western Iran, considering the amount of diesel and gasoline consumption by public and private vehicles such as buses, minibuses and cars and motorcycles, the ecological footprint of transportation was estimated at 0.32 hectares (Gharakhluo et al., 2013).

In this study, we used the ecological footprint model to calculate the energy footprint in the transportation sector in city of Tehran. Also, we calculated the energy footprint of each of the vehicles per passenger and, finally, based on the results, recommendations were made for improving the sustainability of the transportation system in Tehran. 


\section{Materials and Methods}

\section{Studied area}

The studied area waa city of Tehran, the capital city of Islamic Republic of Iran (Fig. 1) and calculations were done based on data related to 2012 (the latest available data). Tehran's population in 2012 was equal to 8.25 million people. In 2012, area of Tehran was equal to $751 \mathrm{~km}^{2}$ and population density was 112 persons per hectare (Transport and traffic studies Company of Tehran, 2012).

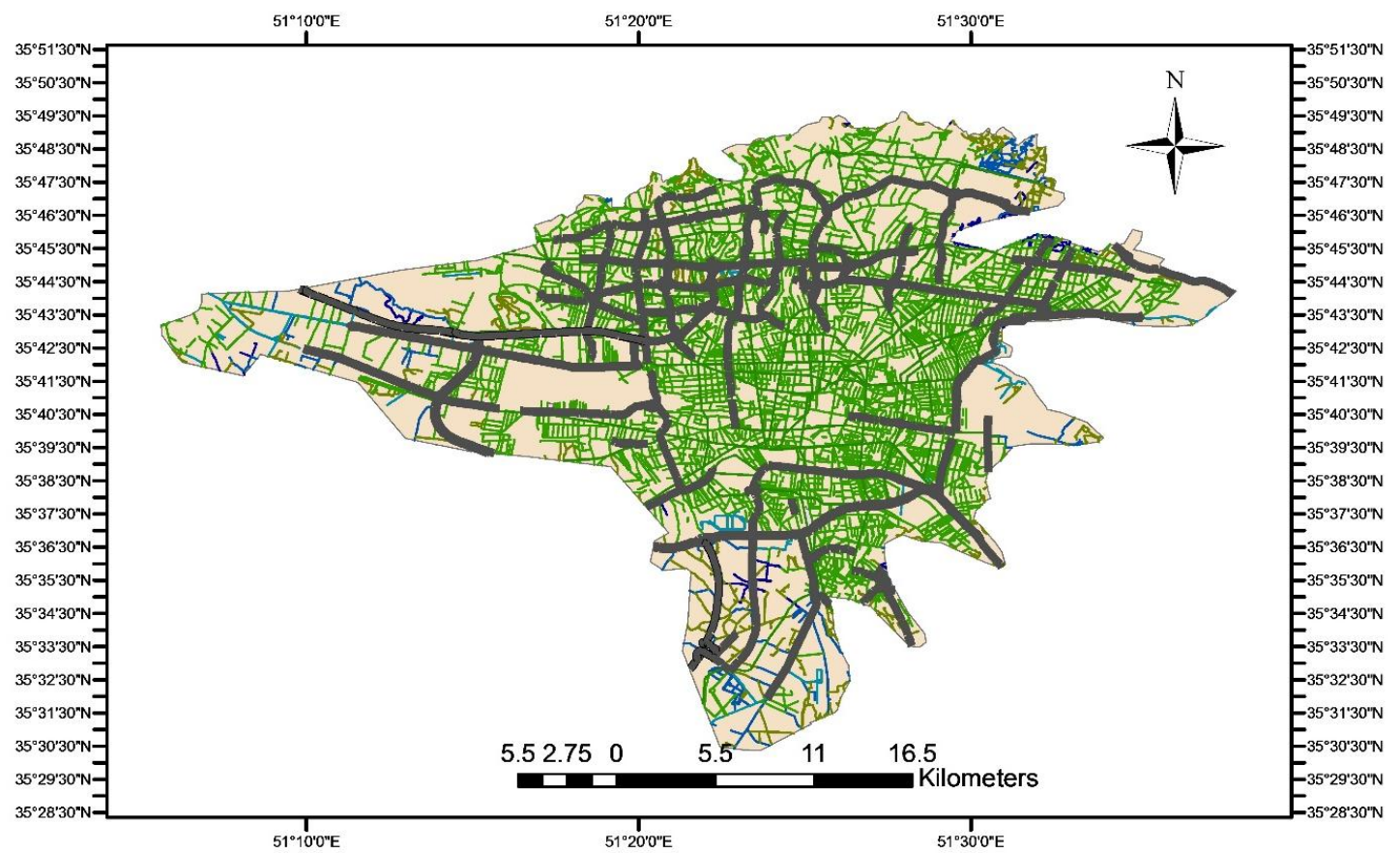

Figure 1. Studied area, Tehran (Tehran Municipality, 2012)

In Tehran, along with demographic changes, the transportation situation has changed as well. Changes in the city's population and transport indices, over the period 2010 to 2013, are shown in Table 1.

Table 1. Changes in the city's population and transport indices over the period 2010 to 2013.

\begin{tabular}{|l|l|l|l|l|}
\hline Year & 2010 & 2011 & 2012 & 2013 \\
\hline Population (million) & 8.1 & 8.15 & 8.25 & 8.6 \\
\hline Number of daily travel (million) & 16.6 & 17 & 17.4 & 17.7 \\
\hline Per capita car ownership & 0.25 & 0.36 & 0.37 & 0.38 \\
\hline Use of public transport rate (percent) & 50.6 & 54.7 & 56 & 56.1 \\
\hline Petrol consumption (million liters) & 3577 & 3538 & 3641 & 3736 \\
\hline Diesel consumption (million liters) & 950 & 1093 & 1337 & 1411 \\
\hline CNG consumption (million cubic meters) & & & 485 & 485 \\
\hline
\end{tabular}

(Source: Transportation and Traffic Studies Company of Tehran, 2012)

Transportation and movement in Tehran are done using various vehicles such as buses, minibuses, taxis, subway, private cars, etc. The total number of daily trips in 
Tehran in 2012 was equal to 17.4 million daily travel. Distribution of daily trips and the share of each of the vehicles in passenger transportation in Tehran are shown in Table 2.

Table 2. Distribution of daily trips in Tehran in 2012

\begin{tabular}{|c|c|c|c|c|c|c|}
\hline \multirow[b]{2}{*}{ System } & \multirow{2}{*}{$\begin{array}{l}\text { Type of } \\
\text { vehicle }\end{array}$} & \multicolumn{2}{|c|}{ Total daily trips } & \multirow{2}{*}{$\begin{array}{l}\text { Movement } \\
\text { Coefficient }\end{array}$} & \multicolumn{2}{|c|}{ Daily movement } \\
\hline & & $\begin{array}{l}\text { Count } \\
\text { (million) }\end{array}$ & Percentage & & $\begin{array}{l}\text { Count } \\
\text { (million) }\end{array}$ & Percentage \\
\hline \multirow{2}{*}{ Private } & Motorcycle & 1.044 & 6 & 1 & 1.044 & 4.7 \\
\hline & Private car & 6.8556 & 39.4 & 1 & 6.8556 & 30.95 \\
\hline \multirow{3}{*}{ Public } & Subway & 2.2272 & 12.8 & 1.5 & 3.3408 & 15 \\
\hline & Bus & 3.0798 & 17.7 & 1.5 & 4.6197 & 20.85 \\
\hline & Minibus & 0.174 & 1 & 1.8 & 0.261 & 1.3 \\
\hline Semipublic & Taxi & 4.0194 & 23.1 & 1.6 & 6.0291 & 27.2 \\
\hline Total & & 17.4 & 100 & & 22.1505 & 100 \\
\hline
\end{tabular}

(Source: Transportation and Traffic Studies Company of Tehran, 2012)

Also, types of fuels used in the transport sector in Tehran and the amount of each are provided in Table 3.

Table 3. Fuel consumption in the transport sector in Tehran in 2012

\begin{tabular}{|l|l|}
\hline Fuel type & Annual consumption \\
\hline CNG (cft) & 17118 \\
\hline Diesel (gallons) & 461868 \\
\hline Petrol (gallons) & 353208464 \\
\hline Electricity (GW) & 370.9 \\
\hline
\end{tabular}

(Source: Transportation and Traffic Studies Company of Tehran, 2012)

\section{Analysis Method}

\section{Estimating ecological footprint of energy in the transport sector}

To calculate the ecological footprint of energy (land area required to absorb or sequester $\mathrm{CO}_{2}$ emitted from burning fossil fuels used in urban transport), the footprint of each fuel is regarded separately because of the differences in the rate of $\mathrm{CO}_{2}$ emissions per volume unit of each fuel (Ebadi et al, 2015; Shayesteh et al, 2014). In addition to the fuel consumed by vehicles traveling along a network, energy consumed in the process of network construction and annual road maintenance must be also reflected in the total transportation network footprint (Chi and Stone, 2005). Wackernagel and Rees (1996) estimated indirect carbon emissions for road construction and maintenance as equivalent to $45 \%$ of the total annual fuel consumed for vehicle travel (Shayesteh et al, 2014). To estimate the energy footprint, the amount of carbon emissions in the construction and maintenance of networks should be also added to the carbon produced by all types of vehicles (Zamba and Hadjibros, 2007). This estimate is multiplied by a carbon equivalence factor to estimate the area of forestland required to absorb the $\mathrm{CO}_{2}$ emitted from fuel consumption in the studied area (Wiedmann and Lenzen, 2007). The equivalence factor for energy footprint is 1.26 (Ewing et al, 2010). 
Footprint is calculated for each of the used fossil fuels and electricity in transport network as follows:

\section{Diesel}

Diesel fuel will produce approximately 138700 BTU per gallon which finally releases 19.95 ton of carbon per billion BTU (Pezzetta and Drossman, 2005) and each hectare of forestland would absorb 1.8 ton of carbon. So, the ecological footprints of diesel fuel are estimated using Equation 1:

$$
E F(d)=\frac{Y C \times 138700 \times 19.95 \times 1.26}{1800000000}
$$

$\mathrm{EF}(\mathrm{d})=$ Diesel EF

$\mathrm{YC}=$ Yearly consumption (gallon)

\section{Petrol}

Petrol would produce approximately 125000 BTU per gallon which finally releases 19.35 ton of carbon per billion BTU (Pezzetta and Drossman, 2005) and each hectare of forestland would absorb 1.8 ton of carbon. So, the ecological footprints of petrol $\mathrm{p}$ are estimated using Equation 2:

$$
E F(P)=\frac{Y C \times 125000 \times 19.35 \times 1.26}{1800000000}
$$

$\mathrm{EF}(\mathrm{g})=$ Petrol EF

$\mathrm{YC}=$ Yearly consumption (gallon)

\section{CNG}

Per cubic foot of CNG, there is an amount of $0.0532 \mathrm{~kg} \mathrm{CO}_{2}$ (Climate Leaders EPA, USA, 2012). Each hectare of forestland would absorb 1.8 ton of carbon. So, the ecological footprints of CNG are estimated using Equation 3:

$$
E F(C N G)=\frac{Y C \times 0.0532 \times 1.26}{1.8}
$$

$\mathrm{EF}(\mathrm{CNG})=\mathrm{CNG} \mathrm{EF}$

$\mathrm{YC}=$ Yearly consumption $(\mathrm{cft})$

\section{Electricity}

To calculate $\mathrm{CO}_{2}$ emissions from electricity consumption, we must first determine the $\mathrm{KJ}$ amount in a certain amount of $\mathrm{kWh}$. Then, the amount of coal used to produce $\mathrm{kJ}$ electricity consumption should be calculated (amount of coal needed to produce $20 \mathrm{~kJ}$ 
of electricity, equal to $1 \mathrm{~g}$ ). Finally, admitting the fact that there is $85 \%$ carbon in coal, it is possible to estimate the released $\mathrm{CO}_{2}$ (Gharakhluo et al, 2013).

\section{Estimating per capita ecological footprint of each vehicle}

In this study, the ecological footprint methods used in Colorado College (Pezzetta and Drossman, 2005) were modified and adapted to carry out the study. Thus, according to the daily consumption of fuels, the number of daily trips and number of people displaced ecological footprint of vehicles were estimate in $\mathrm{m}^{2}$. The amount of fuel consumption per vehicle for transporting a passenger is used to calculate the ecological footprint of each vehicles (Table 4).

Table 4. Amount of fuel consumed to transport a passenger-kilometer by a variety of vehicles

\begin{tabular}{|l|l|l|l|l|l|l|}
\hline Description & \multicolumn{2}{l|}{ Private } & \multicolumn{3}{l|}{ Public and semipublic } \\
\cline { 2 - 6 } & Car & Motorcycle & Taxi & Minibus & Bus \\
\hline $\begin{array}{l}\text { Amount of fuel consumed to } \\
\text { transport a passenger-kilometer(liter) }\end{array}$ & 0.097 & 0.046 & 0.083 & 0.025 & 0.011 \\
\hline
\end{tabular}

(Source: Transportation and Traffic Studies Company of Tehran, 2012)

Also, based on data obtained from Transportation and Traffic Studies Company of Tehran, distance traveled per trip for a variety of motor vehicles is $4.7 \mathrm{~km}$ and, for the subway, it is $12 \mathrm{~km}$.

Therefore, footprint is calculated for each of the vehicles in transport network as follows:

i. Given that several movements take place on each trip, the number of daily trips for each vehicle is multiplied in movement coefficient to obtain the number of movements (Table 2), therefore:

$$
A=\frac{B}{C}
$$

$A=$ Share of a passenger of all daily trips

$\mathrm{B}=$ Number of daily trips done by each vehicle

$\mathrm{C}=$ Number of daily movement done by each vehicle

ii. Now, with regard to the amount of distance traveled by each vehicle per trip, the distance traveled by each passenger per day is calculated according to the following formula:

$$
D=A \times F
$$

$\mathrm{D}=$ Distance traveled by each passenger per day

$\mathrm{A}=$ Share of a passenger of all daily trips

iii. Amount of fuel consumption per passenger per kilometer is calculated according to the following formula:

$$
G=D \times H
$$


$\mathrm{G}=$ Fuel consumption per passenger per kilometer

$\mathrm{D}=$ Distance traveled by each passenger per day

$\mathrm{H}=$ Fuel consumption for movement of a passenger with a variety of vehicles

iv. Finally, per capita ecological footprint is calculated for each vehicle.

The methodology of this study is shown in the Diagram 1 .

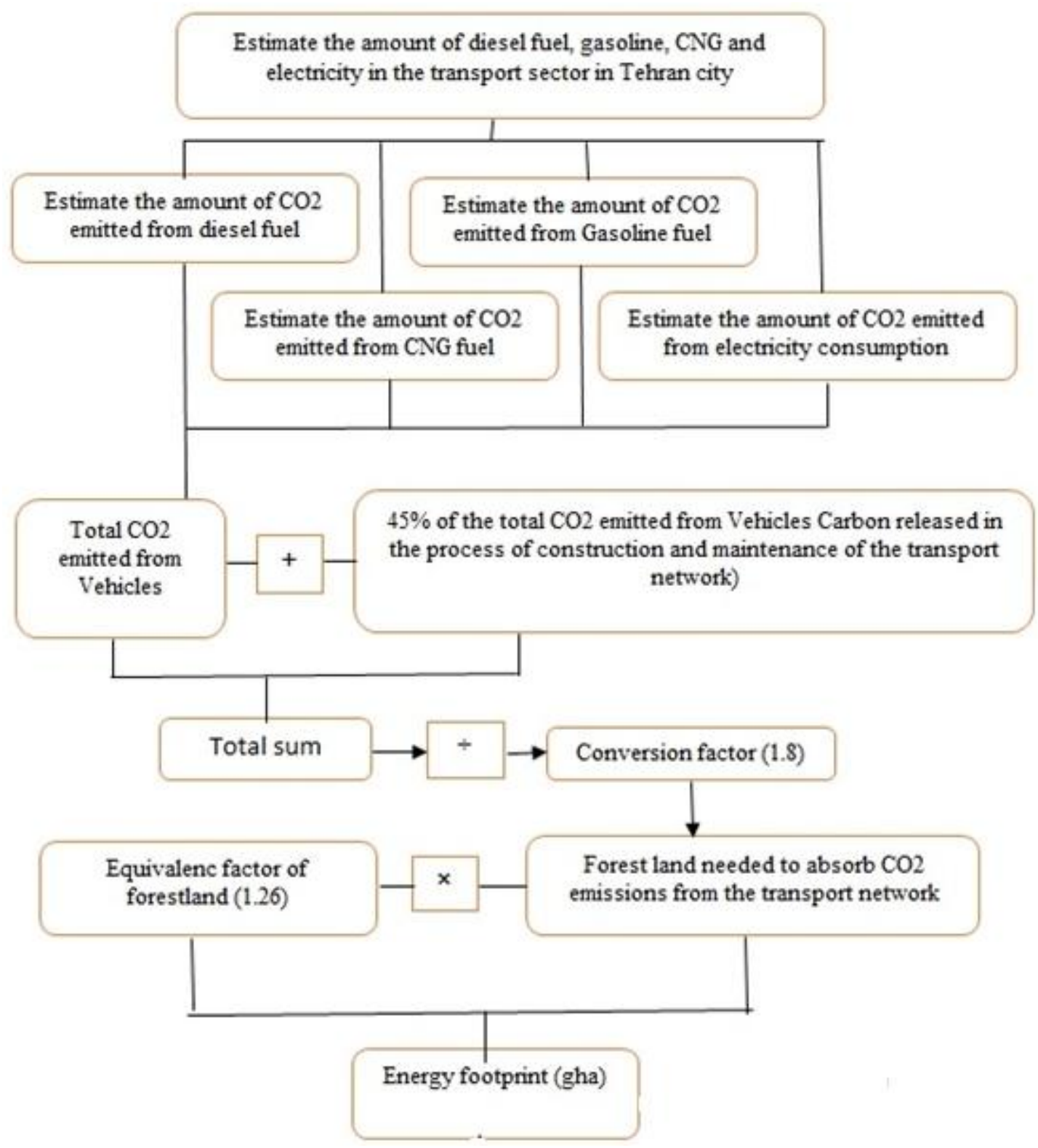

Diagram 1. The method of calculating the ecological footprint of energy in urban transport system 


\section{Results}

\section{Total ecological footprint of energy}

To calculate the energy footprint in the transport sector, the ecological footprint was calculated for each type of fuels and then they were combined. Then energy footprint for road construction and maintenance $(45 \%$ of the carbon released from the consumption of all fuels) was also added.

Ecological footprint of each type of fuel used in transportation sector and energy footprint is provided in Table 5 and Figure 1.

Table 5. Ecological footprint of each type of fuels used in transportation sector in Tehran in 2012

\begin{tabular}{|c|c|c|c|c|c|c|}
\hline $\begin{array}{c}\text { Type } \\
\text { of fuel }\end{array}$ & Petrol & Diesel & CNG & Electricity & $\begin{array}{c}\text { Fuel used in } \\
\text { construction and } \\
\text { maintenance of } \\
\text { roads }\end{array}$ & Total \\
\hline & 1628581.122 & 684145.476 & 624011 & 126507.6 & 1321532.3 & 4384777.5 \\
\hline
\end{tabular}

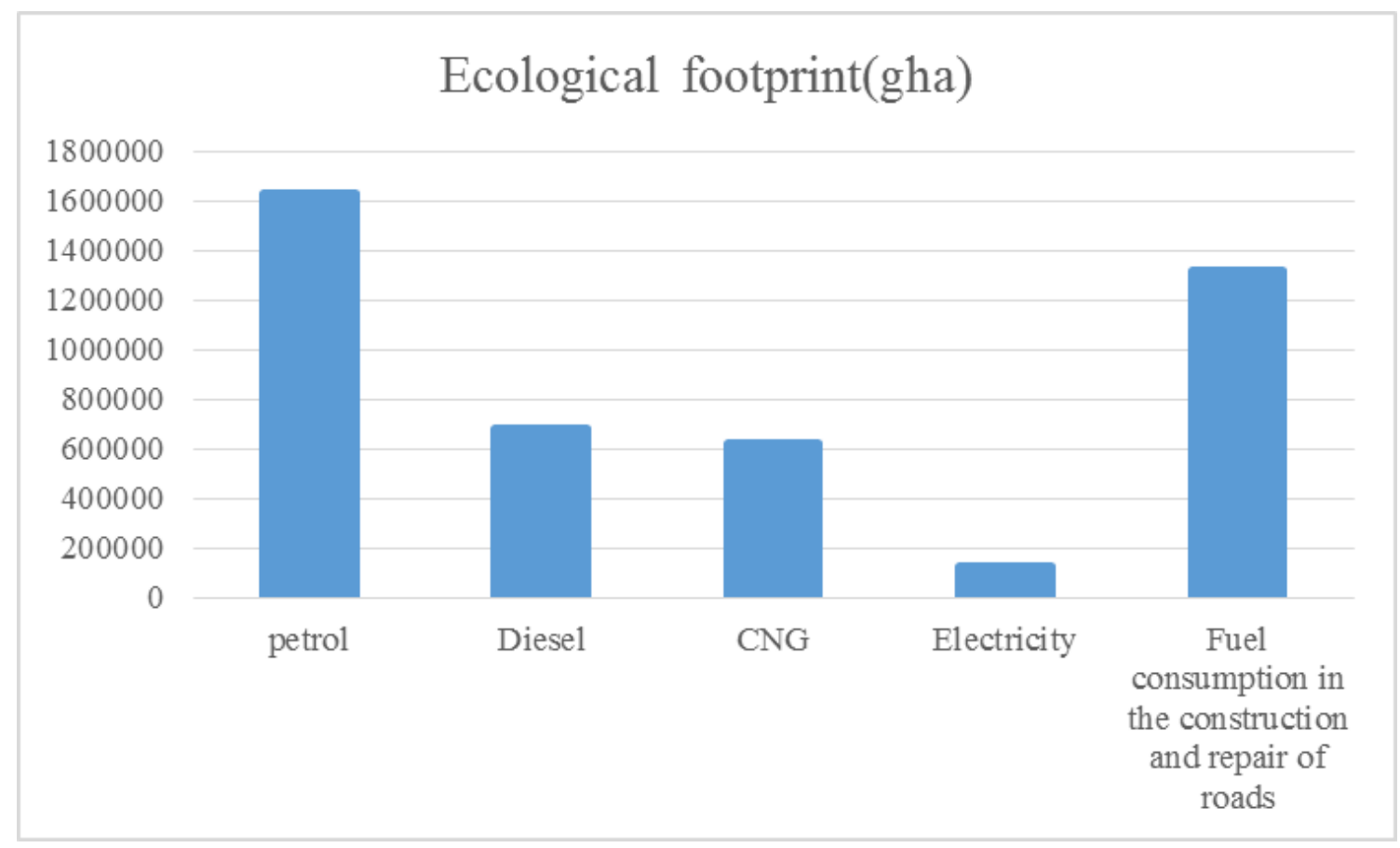

Figure 1. Ecological footprint of each type of fuels used in transportation sector in Tehran in 2012

\section{Ecological footprint of energy of each vehicle per passenger}

Ecological footprint of energy per passenger to each of the vehicles is provided in Table 6 and Figure 2. It should be noted that the type of fuel consumed by buses and minibuses is diesel and that of taxis, motorcycles, and private cars is petrol. Also, in this section, to calculate the per capita ecological footprint subway, annual electricity consumption was divided by the number of annual movements and per capita annual 
consumption was calculated. Then, ecological footprint was calculated per capita electricity consumption.

Table 6. Per capita ecological footprint for each vehicle in city of Tehran in 2012

\begin{tabular}{|c|c|c|c|c|c|c|}
\hline $\begin{array}{c}\text { Type of } \\
\text { vehicle }\end{array}$ & Bus & Minibus & Taxi & Subway & Motorcycle & Private car \\
\hline A & 0.66 & 0.66 & 0.66 & & 1 & 1 \\
\hline $\mathrm{D}$ & 3.102 & 3.102 & 3.102 & & 4.7 & 4.7 \\
\hline $\mathrm{G}$ & $\begin{array}{c}0.009 \\
(\mathrm{gallon})\end{array}$ & $\begin{array}{c}0.020 \\
(\mathrm{gallon})\end{array}$ & $\begin{array}{c}0.068 \\
(\mathrm{gallo})\end{array}$ & $\begin{array}{c}0.0008 \\
(\mathrm{kw})\end{array}$ & $\begin{array}{c}0.057 \\
(\mathrm{gallon}\end{array}$ & $\begin{array}{c}0.12 \\
(\mathrm{gallon})\end{array}$ \\
\hline $\begin{array}{c}\text { Per capita } \\
\text { ecological } \\
\text { footprint } \\
\left(\mathrm{m}^{2}\right)\end{array}$ & $0.138\left(\mathrm{~m}^{2}\right)$ & $0.307\left(\mathrm{~m}^{2}\right)$ & $0.913\left(\mathrm{~m}^{2}\right)$ & $0.002\left(\mathrm{~m}^{2}\right)$ & $0.765\left(\mathrm{~m}^{2}\right)$ & $1.612\left(\mathrm{~m}^{2}\right)$ \\
\hline
\end{tabular}

\section{Per capita ecological footprint of vehicles(m2)}

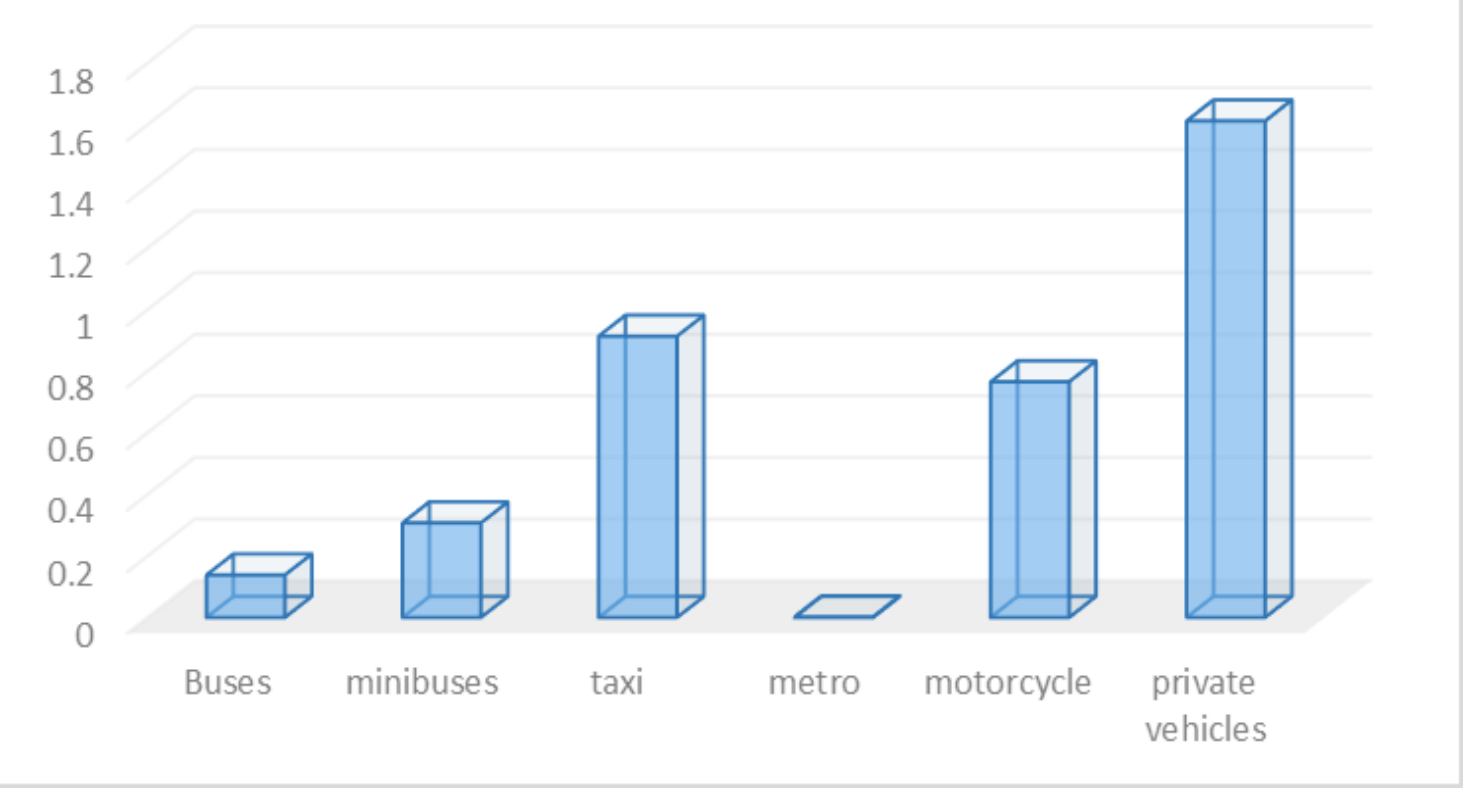

Figure 2. Per capita ecological footprint for each of the vehicles in city of Tehran in 2012

\section{Discussion and Conclusion}

A prerequisite for sustainable development in transportation system is the creation of green spaces to absorb the carbon dioxide produced in this sector. The results of this study showed that the ecological footprint of energy in transportation system in Tehran was equal to 4,384,777.5 gha. This means that Tehran should has 4,384,777.5 ha forest to absorb carbon dioxide produced in the transportation sector; however, the whole forestland in Tehran is equal to 7670.5 ha. In other words, per capita ecological footprint of energy in the transportation system in Tehran equaled $5315 \mathrm{~m}^{2}$, but per capita forestland in Tehran was equal to $9.2 \mathrm{~m}^{2}$, representing the intense unsustainable development in transportation system in Tehran. Thus, Tehran has a deficit of per capita 
forestland required to absorb $\mathrm{CO}_{2}$ emissions from transportation sector with the value of $5305.8 \mathrm{~m}^{2}$ and could not absorb and isolate the released $\mathrm{CO}_{2}$ in transportation sector. On the other hand, Tehran area equal to 751 square kilometers and forestland needed to absorb carbon dioxide released in the transportation sector is 58 times the size of Tehran. This estimation is comparable to other findings like the corresponding estimation for Oslo which is about 22.5 (Aall and Norland, 2002) and estimation for Isphahan which is about 18 (Shayesteh et al, 2014). Therefore, this pollution will disperse in Tehran and the surrounding areas, which causes many environmental problems.

Also, according to the results, it can be concluded that use of the subway system has minimum damaging effects on environmental resources and use of private cars has the most damaging effects on environmental resources. In other words, in the subway system for the movement of a passenger, $0.0008 \mathrm{~kW}$ electricity will be used and, to provide this amount of electricity, $0.002 \mathrm{~m}^{2}$ natural resources (land) is required. However, when using a private car, for every passenger, 0.12 (gallon) of fuel (petrol) is used and, to supply this amount of petrol, $1.612 \mathrm{~m}^{2}$ natural resources (land) is required. As a result, use of a private car results in the faster loss of environmental resources. With a look at the results, we can conclude that, if environmental degradation (erosion of resources caused by fuel consumption) caused by a subway passenger is assumed equal to 1 unit, so environmental degradation caused by any one passenger of buses, minibuses, taxis, motorcycles, and private cars will be equal to $69,185,456,382$, and 806 unit, respectively.

In a same study, in the city of Urmia in Iran, also private cars had the highest ecological footprint (Habibi et al, 2013) and the results of these two studies support each other.

Based on the above discussion, planning to increase sustainability in transportation sector in Tehran should be a priority for policy-makers.

\section{Suggestions}

1) Reducing the use of private cars by applying techniques such as increasing fuel prices, parking cost, area and odd-even traffic control schemes, and expanding culture and education at all levels

2) Increasing satisfactions with using public transportation by techniques such as improving internal and external conditions of the public transport system, reduced latency, reduced waiting time, increased speed and regularity of movement, and creation of special lines by adopting new management practices

3) Using natural gas instead of gasoline and use of hybrid vehicles to optimize fuel consumption

4) Reducing gasoline consumption by gas consuming appliances

5) Restoring and improving urban transport fleet to cope with urban pollution

6) Replacing old cars with a suitable schedule

7) Reducing demand for urban trips with the expansion of the Internet, IT technology, and electronic systems 


\section{REFERENCES}

[1] Aall, C., Norland, T.I. (2002): The Ecological Footprint of the City of Oslo. - Centre for Development and the Environment \& University of Oslo.

[2] Agrawal, M., Boland, J., Filar, J. (2006): The Ecological Footprint of Adelaide City. Center for industrial and applied mathematics institute of sustainable systems and technologies, University of South Australia Mawson Lakes, 26 p.

[3] Barrett, J., Simmons, C. (2003): An Ecological Footprint of the UK: Providing a Tool to Measure the Sustainability of Local Authorities. - Stockholm Environment Institute York, 81p.

[4] Chi, G., Stone, B. (2005): Sustainable Transport Planning: Estimating the Ecological Footprint of Vehicle Travel in Future Years. - J. Urban Planning and Development 131: 170-180.

[5] Climate Leaders - EPA, USA. (2012): Cross-Sector Guidance: Direct Emissions from Mobile Combustion Source. Retrieved January 10, 2012, from Center for Corporate Climate, https://www.epa.gov/climateleadership/center-corporate-climate-leadershipgreenhouse-gas-inventory-guidance\#Cross-Sector

[6] Ebadi, A., Moharram Nejad, N., Rahnamaee, M., Zarandi, S. (2015): Evaluating Sustainable Transportation of Tehran Applying Ecological Footprint Model. - Journal of Pure and Applied Microbiology 9: 495-504.

[7] Ewing, B.D., Moore, S., Goldfinger, A., Oursler, A., Reed, A., Wackernagel, M. (2010): The Ecological Footprint Atlas 2010. - Oakland: Global Footprint Network, 113p.

[8] Faryadi, S.H., Samadpoor, P. (2010): Determining the optimal fit using a variety of transportation methods to reduce the ecological footprint in Tehran. - Journal of Environmental Studies 54: 97-108. (In Persian).

[9] Gharakhluo, M., Hataminejad, H., Baghvand, M., Yalve, M. (2013): Urban Sustainable Development Assessment with Regard to Footprint Ecological Method (Case Study: Kermanshah City). - Journal of Human Geography Research Quarterly 45(2):105-120. (In Persian).

[10] Habibi, K., Rahimi, A., Abdi, M.H. (2013): Evaluation the ecological foot print of urban transportation as a novel approach to sustainable transport planning, Case Study: Urmia. Journal of Planning Geographic Space 5: 99-116.

[11] McIntyre, S., Peters, H.M., Christensen, M., Emmi, P., Martinson, W., Mielke, M., Senbel, M., Stark, D. (2007): The Ecological Footprint of Utah: A Sustainability Indicators Project of the Utah Population and Environment Coalition. - Utah Vital Signs: Salt Lake City, UT, USA, p. 59.

[12] Peters, P., Schouten, F. (2010): Reducing the Ecological Footprint of Inbound Tourism and Transport to Amsterdam. - Journal of Sustainable Tourism 14: 141-156.

[13] Pezzetta, W.E., Drossman, H. (2005): The Ecological Footprint of the Colorado College: An examination of sustainability; http://www.coloradocollege.edu/sustainability/ EcoFootprint.pdf.

[14] Samadpoor, P., Faryadi, S.H. (2008): Determination of the ecological footprint in high density areas of cities (Case Study: Elahiyeh Region of Tehran) - Journal of Environmental Studies 45: 63-72. (In Persian).

[15] Sarayi, M.H., Zarei, F. (2009): Ecological footprint (EF) as an indicator of social sustainability. - Journal of Environmental Studies 50: 15-26. (In Persian).

[16] Shayesteh, K., Melhosseini-Darani, K., Ildoromi, A. (2014): Estimating the Ecological Footprint of Transportation in the City of Isphahan (Iran). - Journal of Current World Environment 9(3): 760-767.

[17] Transport and traffic studies Company of Tehran (2012). Selection of Statistics and Information urban transport of Tehran. - Press of Tehran Municipality, Tehran. 
[18] Wackernagel, M., Rees, W. (1996): Urban Ecological Footprints: why cities cannot be sustainable-and why they are a key to sustainability. - Journal of Environmental Impact Assessment Review 16: 223-248.

[19] Wiedmann, T., Lenzen, M. (2007): On the Conversion between Local and Global Hectares in Ecological Footprint Analysis. - Journal of Ecological Economics 60: 673677.

[20] Wilson, J., Anielski, M., (2005): Ecological Footprints of Canadian Municipalities and Regions. - Federation of Canadian Municipalities.

[21] Woods, P. (2005): Ecological Footprint: North Sydney. Discussion paper. - The University of South Wales and Coastal Council Group Partnership Program.

[22] Zamba, A., Hadjibros, K. (2007): Estimating the Ecological Footprint of Vehicles in the City of Athens. - Proceeding of the 10th International Conference on Environmental Science and Technology Kos Island, Greece 5-7 September 2007. 8p. 